SOPHIST: JURNAL SOSIAL POLITIK KAJIAN ISLAM DAN TAFSIR

VOLUME 3 NOMOR 2 JULI-DESEMBER 2021

(HALAMAN 41-59)

\title{
MODERASI BERAGAMA DI RUANG PUBLIK DALAM BAYANG-BAYANG RADIKALISME
}

\author{
NAZAR NAAMY \& ISHAK HARIYANTO \\ UIN MATARAM
}

nazarpascamataram@gmail.com

ishakharianto@yahoo.co.id

\begin{abstract}
Abstrak
Moderasi beragama dan saling mencintai menjadi cita-cita manusia di dunia ini, karena itu jejak yang paling dasar dalam diri manusia. Maka dari itu, kita harus membenci kekerasan atas nama apapun, baik itu agama, dan kemanusiaan. Manusia harus saling menghargai, menerima, menghormati, dan menjunjung tinggi nilai-nilai kemanusiaan. Kekerasan atas nama agama sering dijadikan alat legitimasi aksi dan reaksi kekerasan, baik radikalisme maupun terorisme oleh para pengusungnya. Kemunculan gerakan radikalisme dan terorisme yang didorong oleh beberapa faktor, baik internal maupun eksternal. Hal ini dapat ditelusuri dari gejala radikalisme di masyarakat, yang ditandai dengan adanya kecenderungan individu maupun kelompok untuk menafsirkan teks secara leterlek serta mengabaikan konteks, ingin penegakan syari'ah, dan cenderung intoleransi terhadap sesama manusia. Dalam artikel ini, penulis menawarkan bahwa moderasi beragama harus hidup di ruang publik, meski dibayang-bayangi oleh radikalisme. Meskipun dalam bayang radikalisme, moderasi beragama harus menjadi jalan keluar di tengah masyarakat yang pluralis dan harus diangkat pada ruang publik sebagai ruang demokratis, yang mana warga negara dapat menyatakan opini, kepentingan, dan kebutuhan mereka secara diskursif. Berkomunikasi mengenai kegelisahankegelisahan politisnya, bebas menyatakan sikap, dan argumen, terlibat dalam membicarakan hal-hal yang berkaitan dengan kepentingan bersama, bukan ditentukan oleh satu individu; Presiden, Tuan guru, Pejabat, Pendeta, Dan Kepala Suku. Ia bersifat bebas dari pengaruh siapapun termasuk pemerintah dan harus mudah diakses oleh semua anggota masyarakat.
\end{abstract}

Kata Kunci: Moderasi Beragama, Ruang Publik, Radikalisme. 


\section{A. Pendahuluan}

Samuel Huntington pernah menulis buku berjudul The Clash of Civilization, The West Against the Rest, atau Foreign Affairs ${ }^{1}$,buku yang meramalkan bahwa di millennium ke tiga ini akan ada benturan antar peradaban, diantaranya adalah peradaban Barat yaitu Amerika beserta sukutunya mewakili sistem kapitalisme dunia, peradaban Timur yaitu Rusia, Cina, Korea Utara, beserta sekutunya mewakili sistem sosialisme komunisme dan terakhir peradaban Islam.

Seolah mengamini apa yang dikatakan Huntington, pada tahun 2001 Amerika Serikat mengobarkan perang global melawan terorisme ${ }^{2}$ sebagai reaksi terhadap aksi serangan pemuda Arab pembajak pesawat jet komersial Amerika Serikat terhadap gedung kembar World Trade Center dan Pentagon pada 11 September 2001. ${ }^{3}$ Akibat peristiwa tersebut melahirkan stigma negatif seperti radikalisme, dan terorisme. Hal ini menjadi sebuah identitas yang selalu dialamatkan kepada umat Islam. Amerika menjadi pemimpin dalam mengomandoi seluruh dunia untuk memberangus jaringan

\footnotetext{
${ }^{1}$ Samuel P. Huntington, "The Clash of Civilization-Or, the West Against the Rest, Foreign Affairs"72 1993.

${ }^{2}$ Stigma negatif teroris yang dimaksud Amerika Serikat adalah umat Islam. Akar persoalannya menurut Huntington terletak pada kenyataan bahwa Islam merupakan peradaban yang identik dengan kekerasan yang berbanding terbalik dengan barat yang toleran, egaliter, dan demokrasi.

${ }^{3}$ Meskipun sampai sekarang masih debatable siapa dalang di balik peristiwa tersebut, Amerika pun sampai sekarang belum mampu membuktikan apa yang dituduhkan.
} 
teroris global seperti al-Qaeda yang diduga sebagai dalang yang bertanggung jawab atas peristiwa 11 September tersebut. ${ }^{4}$

Seluruh media di dunia termasuk media-media besar Nasional di Indonesia menayangkan peristiwa tersebut dan disaksikan rakyat Indonesia sembari mengutuk dalang yang bertanggung jawab atas terbunuhnya banyak orang pada 11 September tersebut. Menurut Noorhaidi Hasan, di Indonesia sendiri, luapan radikalisme dan aksi-aksi kekerasan atas nama jihad yang terjadi dalam satu dasawarsa terakhir telah mendorong Islam politik ke titik paling sentral dalam kajian kesarjanaan tentang dunia Islam. Istilah Islam politik terdistorsi menjadi begitu identik dengan radikalisme dan terorisme, hal ini tak lain karena Istilah Islam politik telah jauh terseret ke dalam retorika yang bergerak liar mengikuti logika perang global melawan terorisme. ${ }^{5}$

Berangkat dari hal tersebut, moderasi beragama menjadi sebuah tantangan tersendiri untuk hidup di wilayah publik, karena berada di bawah bayang-bayang radikalisme. Namun hal ini bukan

4Islamophobia itu berlanjut dan mencapai punjaknya ketika Donald Trump memenangkan pemilu menggantikan Obama. Kebijakan Executive Order atau dikeluarkannya aturan melarang pendatang dari tujuh negara mayoritas muslim untuk memasuki Amerika. Kebijakan tersebut segera menyulut gelombang protes, bahkan kemarahan yang tidak saja warga muslim Amerika, akan tetapi juga masyarakat luas yang non muslim di negeri itu. Belum selesai sampai di sana gelombang protes pun terjadi di mana-mana, demonstrasi besar-besaran terjadi di titik-titik strategis seperti bandara internasional di berbagai kota Amerika Serikat. Dan pada akhirnya keputusan Executive Order itu dibatalkan oleh hakim tinggi Amerika meskipun Trump melayangkan banding untuk kedua kalinya namun tetap ditolak.

${ }^{5}$ Noorhaidi Hasan, Islam Politik di Dunia Kontemporer: Konsep, Geneologi dan Teori, (Yogyakarta: Suka Press, 2012), 1. 
menjadi halangan bahwa moderasi beragama tidak bisa tumbuh di tengah-tengah masyarakat, meskipun masih dibayangi oleh radikalisme.

\section{B. Metodologi}

Dalam membahas wacana moderasi beragama, dalam artikel ini menggunakan metode Critical Discourse Analysis. Dalam pandangan Norman Fairclough Critical Discourse Analysis adalah upaya membongkar maksud dan makna-makna tertentu yang ada di masyarakat di balik wacana yang kasat mata. Analisis wacana kritis ini juga dimaknai sebagai metode dalam membongkar isu sosial, politik dalam mereproduksi, melegitimasi, dan menemukan hubungan dominasi kekuasaan. Fairclough juga memberikan tiga dimensi dalam analisis wacana kritisnya yakni teks, praktik diskursif, dan praktik sosial. Di satu sisi Fairclough juga memformulasikan bahwa terjadinya intertekstualitas yang mengafirmasi interrelasi berbagai teks dan diskursus dalam sebuah teks. Konsep ini juga menghasilkan efek ideologis berupa strukturasi dan restrukturasi tatanan diskursus yang ada. Ketika kekuasaan dan ideologi melekat dalam diskursus, maka intertekstualitas bertindak sebagai mekanisme untuk menjaga atau mengubah relasi dominasi. Pada konteks moderasi beragama di wilayah publik dalam bayang-bayang radikalisme, penulis ingin melihat wacana yang di bangun oleh aktor tertentu dalam satuan ideologi. Seperti yang diaktakan oleh Fairclough bahwa ideologi sebagai "significations/constructions of the reality which are built into several various dimensions of the forms/meanings of discursive 
practices and which contribute to the production, reproduction or transformation of realtions of dominations. Makna dikonstruksi melalui realitas dengan bahasa, baik dalam pemaknaan tentang dunia, relasi sosial, dan identitas sosial bersifat ideologis karena berpotensi untuk memapankan relasi dominasi dalam masyarakat. ${ }^{6}$

Keberadaan ideologi yang berkaitan radikalisme tentu beroperasi dibalik diskursus dan praktik diskursif sosial. Karena keberadaan ideologi radikalisme memiliki potensi besar untuk mempengaruhi dan membentuk pandangan subjek dalam memaknai realitas serta mengarahkan praktik sosialnya. Maka dari itu, analisis wacana kritis berupaya untuk membongkar ideologi,hegemoni yang seolah-olah dianggapmenjadi commonsense di tengah masyarakat dibalik wacana radikalisme yang membayangi moderasi beragama di wilayah publik.

\section{Catatan Buram Radikalisme di Indonesia}

Dalam laporan yang ditulis Mohammad Zulfan Tadjoeddin dari United Nation Support Facility For Indonesian Recovery (UNSFIR) tahun 2002, menunjukkan jumlah kekerasan sejak 1998 melesat naik. Laporan itu berisi, di tahun itu, 124 insiden terjadi dengan korban tewas 1.343 orang. Dua tahun sebelumnya (1996), terjadi 8 insiden dengan jumlah korban tewas 227 orang. Pada tahun 1997, terjadi 15 insiden dengan 131 korban tewas. Setahun pasca Suharto jatuh (1999), jumlah insiden masih terus menanjak,

${ }^{6}$ Norman Fairclough, Discourseand Social Change, (Cambridge: Polity Press, 1992), Hal. 87. 
jumlahnya mencapai 300 insiden dengan 1.813 korban tewas. Pada tahun 2000, menjadi 408 insiden dengan 1.617 korban. Sedangkan pada tahun 2001 menjadi 233 insiden dengan korban terwas 1.065 orang. ${ }^{7}$

Berdasarkan hasil riset berjudul "research on motivation and root cause of terrorism: terhadap 110 pelaku tindak terorisme yang dilakukan oleh The Indonesian research team; Kementerian Luar Negeri, INSEP dan Densus 88 pada tahun 2012 menemukan bahwa berdasarkan tingkat usia para pelaku terorisme tersebut sangat beragam. Usia kurang dari 21 tahun sebanyak 11,8 \%, usia 21-30 tahun sebanyak 47,3\%, usia 31-40 tahun sebanyak 29,1\%, dan usia lebih dari 40 tahun sebanyak 11,8\%. sedangkan pelaku teroris berdasarkan tingkat pendidikan menunjukan bahwa lulusan SD sebanyak 3,6 \%, lulusan SMP sebanyak 10,9 \%, lulusan SMA mendominasi dangan angka 63,6 \%, sementara DO unuversitas sebanyak 5,5\% dan lulusan Universitas sebanyak $16,4 \%{ }^{8}$

Sementara itu sebuah survey yang dilakukan oleh FISIP UIN Hidayatullah Jakarta pada tahun 2011 yang bertemakan "survey radikalisme sosial-keagamaan Mahasiswa UIN/IAIN" dilakukan di 7 provinsi meliputi Jakarta, Yogyakarta, Makasar, Surabaya, Banjarmasin, Sumatera Utara dan Padang. Dengan mengajukan

7 Zuly Qodir, "Peran Ulama Mempertahankan NKRI dan Ke-Indonesia-an", Makalah Disampaikan pada Seminar Nasional "Peran Ulama Menyelamatkan Indonesia" dalam rangka Hut Fakultas Dakwah, 11/11.2014.

${ }^{8}$ M. Harfin Zuhdi, Kontra Radikalisme \& Terorisme "Counter Terhadap Ideology Radikal", (Mataram: Sanabil, 2016), hal. 1. 
sebuah pertanyaan, Jihad dengan motif balas dendam terhadap yang menyerang Islam? hasilnya adalah sebagai berikut;

Sebanyak 23,6 \% setuju, 67,9 \% tidak setuju, selebihnya tidak merespon. Jihad dengan perang mengangkat senjaata sebanyak 37, $1 \%$ setuju, dan 55, 2\% tidak setuju. Jihad dengan mengorbankan nyawa, 28,8 \% menyatakan setuju, dan 65,8 \% tidak setuju. Jihad dengan menggunakan kekerasan $26,7 \%$ setuju, $68,4 \%$ tidak setuju dan selebihnya tidak bersikap. ${ }^{9}$

Baru-baru ini Wahid Foundation bekerja sama dengan LSI melansir sebuah survei. Suvei Nasional yang melibatkan rensponden dari 34 Provinsi di mana survey ini memunculkan sebuah data dan fakta yang mengejutkan bahkan mengkhawatirkan: Mayoritas muslim Indonesia (72\%) MENOLAK tindakan radikal. 7,7 \% yang BERSEDIA melakukan tindakan radikal bila ada kesempatan dan 0,4 yang PERNAH melakukan tindakan radikal.

Temuan di atas menjadi daftar panjang bagaimana intoleransi tumbuh subur di hati rakyat Indonesia. Salah satu alasan mengapa diskursus tentang hubungan antara agama dengan negara memperoleh porsi yang begitu besar di Indonesia, tidak lain karena Indonesia terletak di wilayah pada karakter demografis Asia Tenggara. Pada Tahun 2014 jumlah populasi mencapai 250 juta

9Ibid, hal. 2. 
Jiwa, di mana $87 \%$ beragama Islam, ${ }^{10}$ Indonesia menjadi negara dengan mayoritas penduduk Muslim terbesar di dunia dengan jumlah muslim lebih dari 200 juta jiwa. Namun alasan yang jauh lebih mendasar mengapa isu-isu itu sangat menonjol dalam kajian-kajian mengenai Indonesia terletak pada perubahan tibatiba orientasi politik di negara itu, dan tantangan-tantangan yang dibawanya pada masalah toleransi agama, kebebasan sosial, dan kewarga-negaraan. ${ }^{11}$

Menurut Hefner, Negosiasi dan kompromi politis untuk menegakkan kebebasan beragama di sebagian besar wilayah Eropa Barat dan Amerika Serikat terkait bukan hanya dengan komitmen ontologis pada otonomi individual atau kemurnian keyakinan pesonal. Namun juga upaya penegakan kebebasan beragama adalah usaha pemimpin agama untuk mempromosikan identitas dan kepentingan kelompok, dan kesepakatan-kesepakatan sosial untuk mengakomodasi. Pada tahun-tahun setelah kemerdekaan, kebanyakan riset mengenai agama di Indonesia tidak secara

${ }^{10}$ Tahun 2014, Indonesia tercatat sebagai empat negara dengan jumlah penduduk terbesar di dunia. Sepuluh negara dengan jumlah penduduk terbesar adalah pertama, china 1.355.692.576, kedua, India 1.236.344.631, ketiga, Amerika Serikat 318.892.103, keempat, Indonesia 253.609.643; kelima, Brasil 202.656.788, keenam, Pakistan 196.174.380; ketujuh, Nigeria 177.155.754; kedelapan, Bangladesh 166.280. 712; kesembilan Russia 142.470.272; kesepuluh Jepang 127.103.388. (http://finance.detik.com/read/2014/03/06/134053/2517461/4/negara-denganpenduduk-terbanyak-di-dunia-ri-masuk-4-besar. $06 / 03 / 2014 \quad 15: 04$ WIB, diunduh Jum'at 18 September 2014).

${ }^{11}$ Robert W. Hefner, dalam buku Mengelola Keragaman dan Kebebasan Beragama di Indonesia: Sejarah, Teori dan Advokasi, Program Studi Agama dan Lintas Budaya (Center for Religious and Cross-cultural Studies) Sekolah Pascasarjana, Universitas Gadjah Mada, 2014. 32. 
langsung terkait dengan kebebasan beragama yang didasarkan pada pandangan liberal atau hak asasi manusia, melainkan berkait erat dengan persoalan politik: apakah suatu kerangka kerja kewargaan (civic) yang efektif dapat dikembangkan untuk pengelolaan keragaman agama dan etnis di tengah persaingan elektoral. ${ }^{12}$

\section{Public Sphere di Indonesia}

Indonesia adalah negara kepulauan terbesar di dunia, terdiri dari 17.504 pulau tersebar sepanjang Sabang hingga Merauke, di mana 9.634 pulau belum diberi nama, dan 6.000 pulau tidak berpenghuni. Pulau Kalimantan, pulau Sumatra dan Papua adalah Tiga dari enam pulau terbesar di dunia. Indonesia disebut negara maritim terbesar di dunia dengan luas $93.000 \mathrm{~km}$, dan panjang pantai $81.000 \mathrm{~km}$ persegi, atau hampir $25 \%$ panjang pantai di dunia. Indonesia merupakan negara yang multi etnis, agama (Islam, Kristen Katolik, Protestan, Hindu, Budha, Konghucu), suku dan budaya. Menjadi salah satu negara dengan populasi terbesar di dunia, total penduduknya 240 juta jiwa. ${ }^{13}$ Dalam perjalanannya tumbuh banyak gerakan dan organisasi keagamaan sebelum Indonesia merdeka seperti; Perserekatan Ulama (1911), Muhammadiyah (1912), al-Irsyad (1913), Persis (1920), dan Nahdlatul Ulama (1926). Sementara dari kalangan penganut

${ }^{12}$ Ibid

${ }^{13}$ Agus Dedi Putrawan, Diskriminasi Kaum Ahmadiyah di Lombok NTB "Analisis Nasionalisme Elnest Gellner", dalam Komunitas, Jurnal Pemberdayaan Masyarakat Islam, Volume 7, Nomor 2, Desember 2015, 97. 
Khatolik didirikan Madi Projo (1913) dan di kalangan penganut kristen dibentuk Perkumpulan Kristen (1920).

Isu radikalisme dan terorisme seolah-olah menjadi sajian utama dan menu wajib dalam pemberitaan baik cetak, elektronik, maupun media online. Akibat dari timbulnya New Media ${ }^{14}$ di dunia kontemporer saat ini berita-berita terorisme dan radikalisme kini masuk dan dapat diakses hingga ke pelosok perkampungan Indonesia, ketersediaan jaringan listrik dan luasnya jangkauan internet memungkinkan informasi-informasi yang meludak tersebut mendekati pembacanya sehingga tak jarang media-media penyebar fitnah (hoax) ikut dikonsumsi oleh ramaja, orang tua, maupun anak-anak.

Salah satu cara membendung ini semua adalah mengupayakan hidupnya moderasi beragama di wilayah publik (public sphere) ${ }^{15}$ berkemanusiaan di mana common sense bekerja secara objektif dengan menganggap manusia sebagai subjek bukan

${ }^{14}$ Secara sederhana sebagaimana yang kita ketahui bersama pada masa perang dunia ke II dan awal-awal kemerdekaan kita hanya mengenal Radio dan Televisi milik pemerintah. Kebenaran pada saat itu hanya dimiliki oleh pemerintah, melalui radio dan televisinya (media clasik) menyebarkan informasi kemudian dikonsumsi oleh khalayak (bullet teori) mengontrol dan mengarahkan khalayak seperti menyuntikkan suatu virus (hypodermik komunikasi), hingga reformasi tercapai lahirlah kapitali-kapitalis dengan korporasi media cetak, radio dan tv. Media baru (New Media) timbul setelah adanya internet, Media baru ini terdapat pada dirinya beberapa jenis komunikasi; interpersonal, komunikasi massa.

15 "Setelah bejalannya waktu masuk abad ke-17 maka wilayah komunikasi hanya diperuntukkan bagi kalangan borjuis dan aristokrat tersebut berkembang melalui wilayah tradisional komunikasi dimana publisitas dari representasi terus digoyangkan tidak lagi terancam oleh wilayah publik. ${ }^{15}$ Maka sejak pencerahan terjadi wilayah publik itu mulai dikonsumsi secara massal oleh publik, tanpa adanya otoritas agama dan negara yang mengekang." 
objek, selanjutnya menganggap dialog adalah tujuan, bukan alat itu sendiri. Ruang publik dapat timbul di mana saja. Perkumpulan tiga, atau empat orang membicarakan kepentingan-kepentingan bersama, mengkritisi hukum, sosial, politik, ekonomi, agama, faham radikalisme dan terorisme dapat dikatakan ruang publik.

Wilayah publik (public sphere) ini bermula digagas oleh Jurgen Habermas, seorang sosiolog sekaligus filsuf Jerman dari mazhab frankfurt. Diskursus wilayah publik yang akan dibahas ini tidak hanya sebatas arti, serta konsep semata, namun penulis berupaya melacak pemikiran, karena genealogi pemikiran tidaklah lahir dari ruang yang hampa, akan tetapi memiliki sejarah yang cukup panjang sehingga tema wilayah publik ini menjadi umum kita dengar. ${ }^{16}$

Diskursus wilayah publik sebenarnya sudah beredar dan menjadi sangat penting untuk dibahas, di mana tema ini sudah menjadi pembahasan di dunia Eropa. Dalam sejarah revolusi Perancis, Roger Chartier pernah memberikan pandangannya mengenai wilayah publik, bagi dia wilayah publik adalah: The public sphere as a space for discussion and exchange removed from the sway of state power. ${ }^{17}$

${ }^{16}$ Jurgen Habermas, The Structural Transformation of The Public Sphere, An Inquiry IntoA Category of Bourgeois Society,Terj. Yudi Susanto, (Yogyakarta; Kreasi Wacana, 2007), h. 21.

${ }^{17}$ Miriam Hoexter $d k k$, The Public Sphere In Muslim Societies, (State University of New York Press, 2002), 17. 
Dalam pembentukan opini publik, moderasi beragama harus menjadi kenyataan. Wilayah publik yang menjadi tempat lahirnya moderasi beragama adalah keniscayaan. Dalam hal ini Nilufer Gole mengungkapkan wilayah publik: In the global era, the public sphere is not limited to a single national language community. Rather than the discursive and regulatory or normative aspects of the public sphere, the antagonistic and the experimental dimensions of the public sphere need stressing. The performative and visual repertoire of action staged in a given physical locality opens the way for new forms of public agency and brings the cultural-artistic realm to the fore. Just as Jürgen Habermas did in his works, we need to revisit the relations between the public sphere and democracy and question the autonomous and interdependent aspects of both. ${ }^{18}$

Nilufer Gole banyak bercerita tentang protes, gerakangerakan, baik gerakan wanita dengan kebebasan kerudungnya maupun gerakan gerakan semisal The Gezi Park di ruang publik. Eickelman dalam tulisannya mengatakan: Tema utamanya adalah bahwa peningkatan tingkat pendidikan, kemudahan lebih besar dalam bepergian, dan kemunculan media-media komunikasi baru secara cepat telah mendorong berkembangnya sebuah wilayah publik (public sphere) di masyarakat mayoritas muslim, di mana sejumlah orang tidak hanya terbatas pada elit politik, elit ekonomi, dan orang yang terdidik untuk berbicara dalam isu agama,

${ }^{18}$ Nilufer Gole, The Forbidden Modern "Civilization and Veiling" (USA: The University of Michigan Press, 1996), h. 3-84. Lihat juga Nilufer Gole, "Public Space Democracy", (An article from www.eurozine.com), 9. 
pemerintahan, dan publik. Pragmentasi dalam otoritas publik dan agama ini menghadang otoritarianisme dan akan membawa masyarakat ke arah yang lebih terbuka, persis seperti globalisasi telah diikuti dengan perkembangan seperti gerakan-gerakan hak asasi manusia lintas bangsa dan Vatican II. ${ }^{19}$

\section{E. Membangun Moderasi Beragama di Wilayah Publik}

Membangun moderasi beragama menjadi suatu keniscayaan bagi seluruh umat manusia. Terlebih lagi dengan hadirnya wilayah publik sebagai tempat kebebasan menyampaikan segala pendapat tanpa ada kekangan. Maka dari itu, moderasi beragama seharusnya sudah menjadi common sense masyarakat dalam membina dan menghidupkannya. Moderasi beragama harus menjadi wacana yang mengisi ruang-ruang kemanusiaan di bawah bayang-bayang radikalisme. Moderasi beragama telah menjadi keniscayaan yang harus hidup di tengah-tengah masyarakat sebagaimana Islam sebagai agama yang mengajarkan cinta kasih dalam upaya transformatif dan korektif. Oleh karenanya, Islam tidak dapat mengasingkan diri dari realitasnya sebagai agama pembawa kesejukan dalam meningkatkan moderasi beragama bagi semua makhluk. Islam bukan hanya sekedar simbol perantara antara

${ }^{19}$ Dale F. Eickelman, Islam dan Pluralism, Dalam Bassam Tibi, et al, Etika Politik Islam "Civil Society, Pluralism, dan Konflik, (Jakarta: ICIP, 2005), 158. Lebih lanjut pembahasan tentang Public Islam dapat kita temukan dalam tulisan Armando Salvatore dan James Eickelman, 2004. "Public Islam and Common Good," Et al,, Public Islam and the Common Good. (Leiden; Boston, Brill, 2004), , h. xi-Xxv. Lihat juga Dale F. Eickelman and James Piscatori, Muslim Politics,(United States of America by Princeton University Press, 1996). 
manusia dan Tuhannya, namun lebih luas dari itu, yakni sebagai perantara proses kehidupan manusia dengan alam dan isinya yang menjadi sebuah pesan moderasi.

Moderasi beragama tidaklah lahir dari ruang yang hampa, ia lahir dari ajaran Islam itu sendiri untuk membangun Islam yang selalu menjunjung tinggi pesan kemanusiaan dan selalu terbuka atas segala aspek dalam kehidupan manusia, baik itu agama, adat, suku, budaya, dan bangsa. Moderasi beragama yang lahir dari tubuh Islam itu sendiri merupakan hasil dari dialektika antara teks dan realitas, serta cara pandang antara posisi akal dan wahyu dalam memberikan jalan keluar bagi masalah manusia. Maka dari itu, moderasi menjadi suatu keniscayaan yang harus hidup di di wilayah publik sebagai common sense umat manusia dalam menjaga keutuhan bangsa tanpa harus menghilangkan ajaran nusantara.

Prinsip-prinsip Islam dalam konteks moderasi beragama dapat dijadikan sebagai pijakan dalam melakukan rekonstruksi keberagamaan melalui beberapa pesan. Pertama,Islam diturunkan untuk membebaskan manusia dari belenggu ketertindasan dan pemerasan. Dengan ruh ketuhanan dan semangat kemanusiaan yang tinggi, Islam hadir untuk memberantas segala kezaliman termasuk radikalisme atas nama apapun. Bendera pembebasan inilah yang pertama dikibarkan oleh Islam dalam mewujudkan misinya sebagai penyejuk bagi seluruh umat manusia. Kedua,kesamaan. Islam memiliki pandangan bahwa hubungan manusia dalam kelompok-kelompok sosial adalah sama. Ia tidak mengenal perbedaan. Seluruh manusia memiliki derajat, hak, 
kedudukan dan nilai yang sama dalam memainkan perannya di dunia. Upaya-upaya untuk meningkatkan kualitas diri secara manusiawi mendapat jaminan perlindungan dalam Islam sebagai makhluk yang merdeka. Ketiga, Islam mengajarkan untuk berprilaku seimbang dalam hidup. Prinsip keseimbangan dalam Islam mengharuskan umatnya untuk bersikap kritis, adil dalam memandang dan menempatkan sesuatu, bahkan hubungan dengan Tuhan ditempatkan secara simetris dengan alam dan sesama manusia. Islam tidak menghendaki perpecahan, Islam menghendai moderasi atas nama manusia dan agama.

Prinsip Islam sebagai pesan moderasi keberagamaan bagi seluruh manusia yang menjunjung nilai-nilai dan norma secara demokratis, menghargai, menghormati, mencintai, adalah hal yang penting sebagai landasan bagi hidupnya moderasi beragama dalam wilayah publik. ${ }^{20}$

\section{F. Penutup}

Moderasi beragama; saling mencintai, menghormati menjadi cita-cita manusia di dunia ini, sehingga manusia harus membenci kekerasan atas nama apapun, baik itu agama dan kemanusiaan. Manusia harus saling menghargai, menerima, menghormati dan menjunjung tinggi nilai-nilai kemanusiaan. Moderasi beragama saat ini memiliki tantangan untuk hidup di wilayah publik karena berada dalam bayang-bayang radikalisme. Namun moderasi

${ }^{20} \mathrm{H}$. Nur Solikin AR, Agama dan Problem Mondial Mengurai Dan Menjawab Problem Kemasyarakatan, (Yogyakarta: Pustaka Pelajar, 2013), 90. 
beragama harus hidup dalam wilayah publik guna merekonstruksi pemahaman radikalisme yang tumbuh dan menjadi jalan keluar di tengah-tengah masyarakat yang pluralis, sehingga moderasi beragama harus diangkat pada ranah ruang publik sebagai ruang demokratis. Moderasi beragama harus menjadi wacana yang mengisi ruang-ruang kemanusiaan di bawah bayang-bayang radikalisme. Moderasi beragama merupakan keniscayaan yang harus hidup di tengah-tengah masyarakat sebagaimana Islam sebagai agama yang mengajarkan cinta kasih dalam upaya transformatif dan korektif. Oleh karenanya, Islam tidak dapat mengasingkan diri dari realitasnya sebagai agama pembawa kesejukan dalam meningkatkan moderasi beragama bagi semua makhluk. Islam bukan hanya sekedar simbol sebagai perantara antara manusia dan Tuhannya, namun lebih luas dari itu, yakni sebagai perantara proses kehidupan manusia dengan alam dan isinya sebagai sebuah pesan moderasi. Moderasi beragama tidaklah lahir dari ruang yang hampa, ia lahir dari ajaran Islam itu sendiri untuk membangun Islam yang selalu menjunjung tinggi pesan kemanusiaan dan selalu terbuka atas segala aspek dalam kehidupan manusia, baik itu agama, adat, suku, budaya, dan bangsa. Moderasi beragama yang lahir dari tubuh Islam itu sendiri merupakan hasil dari dialektika antara teks dan realitas, serta cara pandang antara posisi akal dan wahyu dalam memberikan jalan keluar bagi masalah manusia. Maka dari itu, moderasi menjadi suatu keniscayaan yang harus hidup di di wilayah publik sebagai common sense umat 
manusia dalam menjaga keutuhan bangsa tanpa harus menghilangkan ajaran di nusantara.

\section{Daftar Pustaka}

(http://finance.detik.com/read/2014/03/06/134053/2517461/4/nega ra-dengan-penduduk-terbanyak-di-dunia-ri-masuk-4-

besar. 06/03/2014 15:04 WIB, diunduh Jum'at 18 September 2014).

AR, Solikin, H. Nur, Agama dan Problem Mondial Mengurai Dan Menjawab Problem Kemasyarakatan (Yogyakarta: Pustaka Pelajar, 2013).

Dale F. Eickelman, Islam dan Pluralism, Dalam Bassam Tibi, et al, Etika Politik Islam"Civil Society, Pluralism, dan Konflik"(Jakarta: ICIP, 2005).

, Muslim Politics (United States of America by Princeton University Press, 1996). 
Fairclough, Norman, Discourseand Social Change, (Cambridge: Polity Press, 1992).

Gole, Nilufer, "Public Space Democracy" disadur dari www.eurozine.com pada 20 Oktober 2021. -, "The Forbidden Modern Civilization and Veiling" (USA: The University of Michigan Press, 1996).

Habermas, Jurgen, The Structural Transformation of The Public Sphere, An Inquiry IntoA Category of Bourgeois Society,Terj. Yudi Susanto (Yogyakarta: Kreasi Wacana, 2007).

Hamdi, Saipul, Nahdlatul Wathan di Era Reformasi Agama, Konflik Komunal dan Peta Rekonsiliasi (Yogyakarta: KKS Jogjakarta dan Nawa Institute Kalimantan Timur, 2014).

Hardiman, Budi, Fransisco, Ruang Publik (Yogyakarta: Penerbit Kansius, 2010).

Hasan, Noorhaidi, Islam Politik di Dunia Kontemporer; Konsep, Geneologi dan Teori” (Yogyakarta: Suka Press, 2012).

Hefner, W. Robert, dalam buku Mengelola Keragaman dan Kebebasan Beragama di Indonesia: Sejarah, Teori dan Advokasi, Program Studi Agama dan Lintas Budaya; Center for Religious and Cross-cultural Studies (Sekolah Pascasarjana, Universitas Gadjah Mada, 2014).

Hoexter, Miriam dkk, The Public Sphere in Muslim Societies (State University of New York Press, 2002).

Huntington, P. Samuel "The Clash of Civilization-Or, the West Against the Rest, Foreign Affairs" 1993. 
Putrawan, Agus Dedi, "Diskriminasi Kaum Ahmadiyah di Lombok NTB Analisis Nasionalisme Elnest Gellner" Jurnal Komunitas (Volume 7, Nomor 2, Desember 2015). , "Publik Islam dan Masa Depan Demokrasi di NTB" Jurnal Komunitas (Volume 7, Nomor 1, Juni 2015).

Qodir, Zuly, "Peran Ulama Mempertahankan NKRI dan KeIndonesia-an", Makalah Disampaikan pada Seminar Nasional "Peran Ulama Menyelamatkan Indonesia" dalam rangka Hut Fakultas Dakwah, 11/11.2014.

Salvatore, Armando dan Eickelman, James, Public Islam and the Common Good (Leiden: Boston Brill, 2004).

Zuhdi, Harfin, M. Kontra Radikalisme \& Terorisme: Counter Terhadap Ideologi Radikal (Mataram: Sanabil, 2016). 